Canadian Science Publishing
Nechems

Canadian Journal of Zoology Revue canadienne de zoologie

\title{
Richness and zoogeography of ascidians (Tunicata: Ascidiacea) in eastern Canada
}

\begin{tabular}{|r|l|}
\hline Journal: & Canadian Journal of Zoology \\
\hline Manuscript ID & cjz-2016-0087.R1 \\
\hline Danuscript Type: & Article \\
\hline Complete List of Authors: & $\begin{array}{l}\text { Ma, Kevin; Universite Laval, Québec-Océan, Département de biologie; } \\
\text { Memorial University of Newfoundland, Department of Ocean Sciences } \\
\text { Deibel, Don; Memorial University of Newfoundland, Department of Ocean } \\
\text { Sciences } \\
\text { Law, Kenneth; University of British Columbia, Environmental Sciences } \\
\text { Program } \\
\text { Aoki, Mai; University of British Columbia, Biology Program } \\
\text { McKenzie, Cynthia; Fisheries and Oceans Canada, Northwest Atlantic } \\
\text { Fisheries Centre } \\
\text { Palomares, Maria; University of British Columbia, Sea Around Us, Institute } \\
\text { for the Oceans and Fisheries }\end{array}$ \\
\hline Keyword: & $\begin{array}{l}\text { ascidians, indigenous, non-indigenous, cryptogenic, species richness, } \\
\text { zoogeography, eastern Canada }\end{array}$ \\
\hline & \\
\hline
\end{tabular}




\section{Richness and zoogeography of ascidians (Tunicata: Ascidiacea) in eastern Canada}

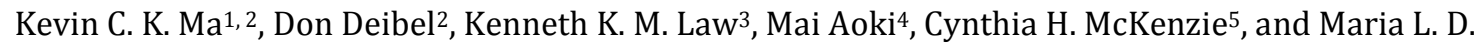
Palomares $^{6}$

${ }^{1}$ Québec-Océan, Département de biologie, Université Laval, Québec, QC G1V 0A6, Canada

2 Department of Ocean Sciences, Memorial University of Newfoundland, St. John's, NL A1C 5S7, Canada

${ }^{3}$ Environmental Sciences Program, University of British Columbia, Vancouver, BC V6T 1Z4, Canada

4 Biology Program, University of British Columbia, Vancouver, BC V6T 1Z4, Canada

${ }^{5}$ Northwest Atlantic Fisheries Centre, Fisheries and Oceans Canada, St. John's, NL A1C 5X1, Canada

${ }^{6}$ Sea Around Us, Institute for the Oceans and Fisheries, University of British Columbia, Vancouver, BC V6T 1Z4, Canada 
Title: Richness and zoogeography of ascidians (Tunicata: Ascidiacea) in eastern Canada

Authors: Kevin C. K. Ma, Don Deibel, Kenneth K. M. Law, Mai Aoki, Cynthia H. McKenzie, and Maria L. D. Palomares

ABSTRACT

Managers and policymakers in eastern Canada embrace science-based management of non-indigenous species and may benefit from having comprehensive regional species checklists at sub-national jurisdictional levels. In this paper, regional checklists provide an account of the richness of ascidians in eastern Canada. Records of 58 ascidians resulted from reviewing 108 published sources, accessing data from two online databases, and collecting some common indigenous ascidian specimens. Analysis comparing the similarity of species among nine regions indicates that there is greater similarity in species composition between contiguous regions than between non-contiguous regions and suggests that there are four zoogeographic clusters in eastern Canada. Our checklists can inform managers and policymakers of the diversity of the ascidian taxa and can minimise taxonomic uncertainties of established non-indigenous and prospective invading species, for example, by identifying indigenous species that are congeners of non-indigenous species. The maintenance of checklists can be a valuable tool for the management of non-indigenous species as baselines to estimate changes in richness and to document the invasion status of non-indigenous species over time. For example, more importance can be placed on the spread of non-indigenous ascidians from one zoogeographic cluster to another than spread within the same cluster.

Keywords: ascidians, indigenous, non-indigenous, cryptogenic, species richness, zoogeography, eastern Canada

INTRODUCTION 
The understanding of the biological diversity of the ascidian fauna in Canada and the United States of America (USA) is relatively coarse in geographic terms. This coarse resolution is a result of collecting ascidian faunal and distributional data (mostly indigenous species) at relatively large spatial scales, often without any information on species abundance. At the continental scale, 82 species of ascidians inhabit the waters of western Canada and western USA (Pellegrin et al. 2007), and 88 are reported from eastern USA (Plough 1978). At smaller spatial scales in north-eastern North America, 37 ascidian species occur in the Gulf of St. Lawrence (GoSL; Brunel et al. 1998), 26 species in coastal Massachusetts (Shenkar and Swalla 2011), and 12 species in the Bay of Fundy (BoF; Shenkar and Swalla 2011). The rather low number of ascidian species reported for the BoF compared to neighbouring regions suggests either a low ascidian diversity, or that the ascidian faunal composition is poorly studied and the species richness underestimated. There may be a knowledge gap in the systematics of ascidians due to a low number of studies and a lack of taxonomic expertise in a given region (Schander and Willassen 2005; Kim and Byrne 2006).

Marine ecosystems are presently threatened by the invasion of non-indigenous ascidian (NIA) species, which have become both a Canadian (LeGresley et al. 2008; Ramsay et al. 2008a; Sephton et al. 2011; Deibel et al. 2014; McKenzie et al. 2016) and global problem, due to the displacement of native and commercially important species (Lambert 2007, 2009; Locke and Carman 2009; Zhan et al. 2015; Carman et al. 2016). In response, a growing number of investigators have aimed to understand the process, detection, and prevention of NIA introductions, to minimise their detrimental ecological and economic impacts and to control their potential spread. In southern California, as many as 14 NIA species have been identified (Lambert and Lambert 1998, 2003). In contrast, only five NIA species (Botrylloides violaceus Oka, 1927, Botryllus schlosseri (Pallas, 1766), Ciona savignyi Herdman, 1882, Didemnum vexillum Kott, 2002, and Styela clava Herdman, 1881) have been reported from British Columbia (Lambert 2003; Carver et al. 2006a, 2006b; Clarke and Therriault 2007; Epelbaum et al. 2009; Lambert 2009), and six NIA species (Ascidiella aspersa Müller, 1776, B. violaceus, B. schlosseri, D. 
vexillum, Diplosoma listerianum (Milne-Edwards, 1841), and S. clava) and one cryptogenic ascidian species (Ciona intestinalis (Linnaeus, 1767), formerly C. intestinalis type B) have been reported in eastern Canada (Carver et al. 2006a, 2006b; Clarke and Therriault 2007; Locke et al. 2007; Sephton et al. 2011; Deibel et al. 2014; Moore et al. 2014; McKenzie et al. 2016). Presently, eastern Canada is susceptible to the potential introduction of other NIA species, such as those identified by Locke (2009), via shipping and climate-change processes. This susceptibility underscores the value of up-to-date knowledge on the distribution of NIA species at smaller spatial scales and for under-represented regions (e.g., the Arctic Ocean).

While the identification, invasion history, and geographic distribution of NIA species is useful information to industry, management, and policymakers, it is also valuable to have an understanding of indigenous ascidian (IA) species. Unfortunately, a good account of the local diversity and distribution of IA and NIA species can be inaccessible, incomplete, or missing. For instance, the IA fauna of coastal and offshore waters of Newfoundland might not be fully known because many specimens held at the provincial museum in St. John's have not been identified to species (K.C.K. Ma, personal observation) and might not be verifiable because older specimens described in the literature may have since been lost.

The main purpose of this investigation was to compile checklists of IA and NIA ascidian species of eastern Canada and to compare the species richness of the ascidian taxa among the coasts of the Arctic, Labrador, insular Newfoundland, the GoSL, and the Canadian Maritimes. We tested the hypothesis that there are significant differences in the composition of the ascidian fauna among regions, such that the faunal similarities between contiguous regions (i.e., having water bodies that share a boundary) are greater than between non-contiguous regions.

MATERIALS AND METHODS 
Occurrence records

Ascidian records from 1852 to the present were collected from 108 published sources and two online databases: the Ocean Biogeographic Information System (OBIS; OBIS 2015); and the Global Biodiversity Information Facility (GBIF; GBIF 2015), accessed on 30 September, 2015, at http://www.iobis.org/ and http://www.gbif.org/, respectively. See Appendix 1 for a list of sources organised by species and by region. We searched all ascidian records that were geographically referenced to Canada and excluded records from western Canada post hoc. Records that were not identified to the species level were excluded with the exception of Heterostigma sp. Heterostigma sp. was included because this genus is not represented by any species found in eastern Canada (see Goldsmit et al. [2014]). OBIS and GBIF contained ascidian occurrence records in 11 and 9 datasets, respectively (Appendix 1).

All scientific names were updated to be consistent with the World Register of Marine Species, which was accessed on 12 December, 2015, at http://www.marinespecies.org/ (WoRMS Editorial Board 2015). All records from eastern Canada were categorised by region as follows: (1) the Arctic (from the Beaufort Sea to Baffin Bay; including Hudson Bay), (2) Labrador, (3) insular Newfoundland, (4) the Atlantic waters of Nova Scotia, (5) the Gulf of St. Lawrence (GoSL) waters of Quebec, (6) Prince Edward Island (PEI), (7) the GoSL waters of New Brunswick, (8) the GoSL waters of Nova Scotia, (9) the Bay of Fundy (BoF) waters of New Brunswick, and (10) the BoF waters of Nova Scotia (Figure 1).

Indigenous species with two or fewer records were evaluated for inclusion in the checklist. Didemnum roseum Sars, 1851 is an arctic species that is restricted to the Old World and is a close ally of the relatively common Didemnum albidum (Verrill, 1871) in the New World (Van Name 1945). Halocynthia aurantium (Pallas, 1787) is restricted to the Pacific coast and is very similar to the widely distributed Halocynthia pyriformis (Rathke, 1806) on the Atlantic coast (Van Name 1945; Millar 1966; Haydar 2010). Thus, to conform to the conventional treatment of their taxonomy based on their distributions, we considered records of $D$. roseum in eastern Canada to be D. albidum and records of $H$. 
aurantium in eastern Canada to be H. pyriformis. We are uncertain about the identification of Aplidium translucidum (Ritter, 1901) (record from Kongulaksiarvik, Labrador), Araneum sigma Monniot C. \& Monniot F., 1973 (offshore waters of Labrador), Eugyra pedunculata Traustedt, 1886 (Cambridge Bay, Nunavut), Minipera papillosa Monniot C. \& Monniot F., 1974 (offshore waters of Labrador), Minipera pedunculata Monniot C. \& Monniot F., 1974 (offshore waters of Labrador), Molgula pugetiensis Herdman, 1898 (Port de Grave, Newfoundland), Polycarpa spongiabilis Traustedt, 1883 (Halifax, Nova Scotia), Pseudodiazona abyssa Monniot C. \& Monniot F., 1974 (offshore waters of Labrador), and Styela squamosa Herdman, 1881 (reported as Styela milleri Ritter, 1907; between Halifax and La Have Bank, Nova Scotia), listed in OBIS and GBIF. These nine species were not included in the checklist because of a lack of corroborating published literature to support their inclusion. Although Clavelina concrescens Hartmeyer, 1924, Lissoclinum wandeli Hartmeyer, 1924, and Styela gelatinosa (Traustedt, 1886) have been reported from the Davis Strait, off the west coast of Greenland, these species were not included because there are no other records from the coasts of Canada, and we believe these are primarily Old World species (Van Name 1945; Millar 1966). Molgula occidentalis Traustedt, 1883 (record from northern GoSL waters of Quebec) was excluded because it is distributed from North Carolina to the West Indies (Van Name 1945). The checklist included Ascidia dijmphniana (Traustedt, 1886) (record from Labrador) because it is a rare arctic species that has been documented in Baffin Bay (Van Name 1945), and Hartmeyeria arctica Korczynski, 1989 because it was originally described in Mason Bay, Northwest Territories (Korczynski 1989). As mentioned above, Heterostigma sp. is included in this checklist because there are no known species in the Arctic and in eastern Canada that belongs to this genus (Goldsmit et al. 2014). The checklist included Molgula arenata Stimpson, 1852 (a questionable record from the BoF waters of New Brunswick) because it is distributed from Massachusetts to New Jersey (Haydar 2010). As a result, a total of 13 ascidian species found in the sources we consulted were excluded from the checklist (Table 1).

Indigenous, non-indigenous, and cryptogenic criteria 
Each ascidian species in this study was classified as indigenous, non-indigenous, or cryptogenic based on their historical, biogeographic range. Ascidiella aspersa, B. schlosseri, B. violaceus, D. listerianum, D. vexillum, and S. clava are considered non-indigenous in eastern Canada (Carver et al. 2006a, 2006b; Clarke and Therriault 2007; Locke 2009; Mackenzie 2011; Moore et al. 2014). At a continental scale, Yund et al. (2015) suggest that B. schlosseri can be considered cryptogenic to north-eastern North America based on molecular evidence. However, in this study, B. schlosseri is not classified as cryptogenic in eastern Canada because Yund et al.'s (2015) findings were determined from specimens from only Nova Scotia (12 sites) and PEI (1 site), which may not be representative of all of eastern Canada. At a national scale, $C$. intestinalis (formerly C. intestinalis type B) is considered cryptogenic to eastern Canada; however, at a sub-national scale, this species is considered indigenous in the Arctic and non-indigenous in Îles-de-la-Madeleine (Quebec), PEI, and insular Newfoundland (see below). We assumed all other ascidian species to be indigenous.

Ascidiella aspersa is indigenous to the waters throughout Europe (including the Mediterranean Sea and the British Isles; Stachowicz et al. 2002; Carlton 2009; Moore et al. 2014). Botrylloides violaceus and S. clava are indigenous to the north-western Pacific Ocean (Carlton 1979; Carver et al. 2006b; Clarke and Therriault 2007; Goldstien et al. 2011; Lejeusne et al. 2011). Botryllus schlosseri is widely considered indigenous to the Mediterranean Sea (Carver et al. 2006b; Lejeusne et al. 2011). Molecular evidence suggests that a clade of $B$. schlosseri (sub-clade Bs2) may be indigenous to north-eastern North America (Yund et al. 2015). Yund et al. (2015) recommend that B. schlosseri be considered cryptogenic in northeastern North America because of the admixture of indigenous and non-indigenous haplotypes in some populations sampled in north-eastern North America. Didemnum vexillum is indigenous to Japan (Stefaniak et al. 2012). Diplosoma listerianum may be indigenous to the North Sea and the English Channel, where it was first described, but this species should be considered cryptogenic in European waters until more evidence is available (Haydar 2010; Mackenzie 2011). B. violaceus was likely introduced to eastern North America via transport of aquaculture material (Dijkstra et al. 2007), while A. aspersa, B. schlosseri, D. listerianum, D. vexillum, and S. clava may have been introduced via 
fouled ship hulls (Van Name 1945; Bullard et al. 2007; Dijkstra et al. 2007; Therriault and Herborg 2008a; Haydar 2010; Mackenzie 2011).

Molecular and morphological evidence (Brunetti et al. 2015) and a cross-breeding study (Caputi et al. 2007) suggest that $C$. intestinalis type A and type B are two distinct species. They have been renamed Ciona robusta Hoshino \& Tokioka, 1967 (formerly Ciona intestinalis type A) and Ciona intestinalis (Linnaeus, 1767) (formerly Ciona intestinalis type B). In the present study, we assume that $C$. intestinalis is the only Ciona sp. in eastern Canada based on the report of C. intestinalis type B from Newfoundland (Sargent et al. 2013) and the lack of reports of C. intestinalis type A from eastern Canada.

Ciona intestinalis is generally believed to be indigenous in European waters (Carver et al. 2006a; Therriault and Herborg 2008a; Zhan et al. 2010) and in arctic and subarctic waters (Van Name 1945; Berrill 1950; Millar 1966). Previously, there are several varieties of $C$. intestinalis described in the literature, including formae typica, gelatinosa, longissima, and tenella (Van Name 1945; Millar 1966; Therriault and Herborg 2008b). Formae gelatinosa and longissima were reported from arctic and subarctic waters of northern Europe (Van Name 1945; Millar 1966). Therefore, we considered $C$. intestinalis from the arctic waters of northern Canada (records from Foxe Basin and north-eastern Baffin Island; Atkinson and Wacasey 1989; Aitken and Fournier 1993) to be an indigenous species. Forma tenella is now no longer used, but was reported from northern New England and the BoF (Verrill 1871; Van Name 1945; Millar 1966). For the present study, C. intestinalis from the Atlantic waters of Canada, the GoSL, and the BoF can be considered as a cryptogenic species, except in Îles-de-laMadeleine (Quebec), PEI, and insular Newfoundland. On these islands, the absence of historical records suggests that $C$. intestinalis can be considered as a non-indigenous species.

As a result of empirical and genetic evidence (Haydar 2010), Molgula manhattensis (De Kay, 1843), previously considered cryptogenic in eastern Canada, is believed to be indigenous. In the present study, we treat M. manhattensis as indigenous in eastern Canada despite its controversial origins. 
Analysis

The pair-wise similarity between regions was evaluated with the Sørensen similarity index (Sørensen 1948), by calculating the quotient of similarity (QS),

$$
Q S=\frac{2 C}{A+B}
$$

where $A$ and $B$ represent the number of ascidian species in regions $A$ and $B$, respectively, and $C$ the number of species shared between these two regions. Accordingly, $Q S$ values range from 0 (dissimilar) to 1 (similar). We chose the Sørensen similarity index because the regions are distinct areas and the data consist of the presence and absence of ascidian species.

Non-metric, multi-dimensional scaling (nMDS) of ascidian species from nine regions of eastern Canada was generated using PRIMER (version 6). The GoSL waters of New Brunswick was not included in the nMDS because of the low richness of ascidian species $(n=2)$ in this region. Zoogeographic clusters were identified by applying a Simprof test with a 5\% significance level.

Indigenous ascidian specimens from dive surveys

SCUBA divers from Memorial University of Newfoundland collected specimens of IA species from coastal harbours around Newfoundland between September 2009 and February 2010. Indigenous specimens were transported to the laboratory, where they were maintained alive in flowing unfiltered seawater. In the laboratory, living ascidian specimens were photographed within a few days of collection with a 7.1 megapixel, Canon PowerShot SD750 digital camera. A measuring tape was positioned under the glass beaker in each photograph to provide scale to the nearest $1 \mathrm{~mm}$. The 
specimen was left undisturbed for $\geq 1$ min prior to photography.

RESULTS

Checklist

A total of 58 ascidian species (including Heterostigma sp.) from 10 families and 31 genera has been reported from eastern Canada (Table 2). We determined that 50 of these species are indigenous (photographs of common IA species collected from dive surveys are shown in Figure 2), six are nonindigenous, and two are cryptogenic (Appendix 2). Thirty-five species (60\%) belong to the order Stolidobranchia, 15 (26\%) to Aplousobranchia, and eight species (14\%) to Phlebobranchia. Forty-one species were geographically referenced to the Arctic, 27 to Labrador, 36 to insular Newfoundland, and 36 to the Atlantic waters of Nova Scotia (Table 2). In the GoSL, 35 species were referenced to Quebec, 17 to PEI, two to New Brunswick, and 11 to Nova Scotia (Table 2). In the BoF, 34 species were referenced to New Brunswick, and 16 to Nova Scotia (Table 2). Notably, few species were reported from the BoF waters of Nova Scotia and the GoSL waters of PEI, New Brunswick, and Nova Scotia. Also, there are no reports of NIA species in the Arctic and Labrador regions. Furthermore, the distribution of all the ascidian species in this study (except that of Heterostigma sp., which is not known) were reviewed and categorised (Appendix 2). Based on the categories established by Haydar (2010), 26 ascidian species (46\%) were limited to arctic and/or subarctic waters, 16 species (28\%) exhibited a continuous amphi-Atlantic distribution, 11 (19\%) exhibited a disjunct amphi-Atlantic distribution, and four (7\%) were restricted to the north-eastern coast of North America.

There are three NIA species (B. violaceus, D. vexillum, and S. clava) in eastern Canada, which have IA species that are congeners. Botrylloides aureum (Sars, 1851) is an indigenous botryllid species reported in the Arctic, mainland Labrador, insular Newfoundland, and the GoSL waters of Quebec (Table 2). The indigenous didemnids D. albidum (Figure 2 E) and Didemnum candidum Savigny, 1816 are reported in 
eastern Canada. D. albidum is more widely distributed (reported from nine out of ten regions investigated in this study) than is the patchily distributed D. candidum (reported from the GoSL waters of Quebec and the BoF waters of New Brunswick; Table 2). Three indigenous styelid species were identified in eastern Canada: Styela canopus (Savigny, 1816), Styela coriacea (Alder \& Hancock, 1848), and Styela rustica Linnaeus, 1767 (Table 2). Geographically, all three of these styelids are found in the Atlantic waters of Nova Scotia (Table 2). In addition, S. coriacea and S. rustica are found in the Arctic, Labrador, insular Newfoundland, and the GoSL, and S. canopus and S. coriacea in the BoF waters of New Brunswick (Table 2).

Similarity of ascidian fauna among regions

Among the most similar regions in terms of ascidian fauna were insular Newfoundland and the GoSL waters of Quebec $(Q S=0.79)$, the GoSL waters of Quebec and the Atlantic waters of Nova Scotia $(Q S=$ 0.79), and PEI and the GoSL waters of Nova Scotia ( $Q S=0.79$; Table 3). The GoSL waters of New Brunswick region was the least similar region to the other regions of this study (QS ranged from 0.00 0.29; Table 3). The regions with highest mean values of QS were insular Newfoundland (mean $Q S=0.61$ \pm 0.22 ) and GoSL waters of Quebec (mean $Q S=0.61 \pm 0.21$; Table 3). The region with the lowest mean value of QS was the GoSL waters of New Brunswick (mean $Q S=0.13 \pm 0.10$; Table 3).

An nMDS analysis of the matrix of Bray-Curtis similarities in species composition revealed significant structure among the nine regions (the GoSL waters of New Brunswick region was excluded from the analysis due to the low number of species; Figure 3). This analysis indicates that neighbouring (contiguous) regions are more similar in species composition than are distantly separated (noncontiguous) regions. In addition, superimposed results from a cluster analysis revealed four significant clusters at greater than $60 \%$ and less than 70\% similarity (clusters: Arctic-Labrador, Atlantic-northern GoSL, southern GoSL, and BoF waters of Nova Scotia). The Arctic-Labrador cluster is comprised of the Arctic and Labrador regions. Insular Newfoundland, the Atlantic waters of Nova Scotia, the GoSL waters 
of Quebec, and the BoF waters of New Brunswick regions are grouped into the Atlantic-northern GoSL cluster. PEI and the GoSL waters of Nova Scotia regions form the southern GoSL cluster. Lastly, the BoF waters of Nova Scotia region forms its own cluster. This pattern is robust, with a 2D stress level of 0.04 (Figure 3).

DISCUSSION

The checklists presented in this study provide distributional information, species-by-species, and an account of the richness of ascidian species, region-by-region, of eastern Canada. Previously, a comprehensive description of ascidian species indigenous to different regions of eastern Canada was difficult to access in the literature. For instance, distributional information compiled by Van Name (1945), one of the most comprehensive and authoritative monographs of the ascidian fauna of North and South America, and by Brunel et al. (1998), for the GoSL, was organised by species rather than by region.

The geographic sizes (e.g., the length of coastline) of the ten regions defined in this study are unequal (the Arctic region being the largest and, perhaps, the most complex). Therefore, larger regions could be divided into smaller regions. For example, future investigators might consider separating the GoSL waters of Quebec into possibly three smaller regions; for example, the northern coast of the GoSL (including Anticosti Island), the southern coast of the GoSL (i.e., the Gaspé Peninsula), and the Îles-dela-Madeleine. The division of larger regions into smaller ones may help to identify potential areas of knowledge gap (e.g., the southern GoSL in the present study).

In the southern GoSL and the BoF waters of Nova Scotia, the low number of species suggests a possible knowledge gap in the systematics of ascidians in this area, e.g., the GoSL waters of Nova Scotia (11 species; 7 sources), and the GoSL waters of New Brunswick (2 species; 3 sources). The low species richness in the these regions may be due to a paucity of ascidian records from published sources of 
literature and online databases, or lack of experts to morphologically identify ascidian specimens. Taxonomic expertise in a given region may be increasingly important to the management of NIA because some ascidian species are difficult to visually distinguish from closely related species. Therefore, regional checklists provide an account of IA species useful to managers and policymakers at relevant sub-national jurisdictional levels, because IA species that are congeners of established and prospective NIA species can be rapidly identified. The ability to positively identify known indigenous species that are congeners of possible non-indigenous species can minimise taxonomic uncertainties, especially if there are gaps in knowledge due to lack of taxonomic expertise.

In this study, the total number of sources of ascidian records (from published literature, online databases, and collection of specimens) was unevenly distributed among the regions. Also, the number of ascidian records varied among the sources. One possible explanation for this uneven distribution of data may be that the number and frequency of local ascidian faunal surveys is related to the proximity to historical and contemporary centres of biological research activities (government and academia). Yet, our findings indicated that neighbouring (contiguous) regions are more similar than distantly separated (non-contiguous) regions.

The identification of four zoogeographic clusters for the ascidian taxa in eastern Canada might be seen as useful areas for the management of NIA species. For example, the spread of NIA species from one cluster to another could represent a relatively more important management and policy issue than the spread of NIA species within the same cluster. However, the clusters and regions defined in this study are convenient geographic units and should not be viewed as distinct boundaries for the management of NIA species. As more NIA species invade in the future, the composition of the ascidian fauna among clusters and among regions may become increasingly more similar. Hence, the compilation and maintenance of species checklists of multiple neighbouring regions can be a valuable tool for the management of non-indigenous species because it serves as a baseline to estimate changes in species richness and to monitor the spread of non-indigenous species over time. Unfortunately, the 
species checklist presented in this study includes many historical ascidian records and does not take into account possible extirpation of species from a given region.

The zoogeographic clusters identified in this study broadly correspond to the marine ecological provinces identified by Longhurst (2007) and Spalding et al. (2007). The partitioning of the ocean into provinces by Longhurst (2007) takes into consideration physical (e.g., regional circulation and stratification) and biological (e.g., surface chlorophyll) factors. According to Longhurst (2007), eastern Canada is comprised of two provinces: the Boreal Polar Province (BPLR), and the Northwest Atlantic Shelves Province (NWCS). The Arctic and Labrador regions belong to BPLR and the other regions of this study are part of NWCS. Longhurst (2007) further partition NWCS into smaller provinces:

Newfoundland shelf (including the Grand Banks and Flemish Cap), the GoSL, Northeast shelf and Gulf of Maine (from Cabot Strait to Cape Hatteras), and South Atlantic Bight (from Cape Hatteras to the Florida Keys). For eastern Canada, the partitioning of provinces in Spalding et al. (2007) is consistent with Longhurst (2007), i.e. the Arctic province corresponds to BPLR and the Cold Temperate Northwest Atlantic province to NWCS.

Previously, at a larger spatial scale, Naranjo et al. (1998) used ascidian diversity to delineate marine boundaries along the Atlantic-Mediterranean shores, where eastern Canada was represented by two out of 17 biogeographical areas: Arctic, and north-western Atlantic (very similar to the provinces described by Longhurst [2007] and Spalding et al. [2007]). At this inter-continental scale, Naranjo et al. (1998) found that these two areas are grouped into one zoogeographic cluster (Bray-Curtis similarity) based on presence-absence of genera and species. For the case of eastern Canada, our study shows that this coarse understanding of ascidian biodiversity in terms of geographic resolution can be refined, and thus reveal meaningful structure in faunal composition at finer spatial scales.

ACKNOWLEDGEMENTS 
We thank A. Callahan, R. O’Donnell, D. Poitras, P. Sargent, and M. Schofield for their field assistance and expertise in the collection of specimens. Figure 1 was improved with the help of Tara Connelly. We also thank P. Gagnon, G. Lambert, J. B. Lowen, R. J. Thompson, and anonymous reviewers for comments that improved this manuscript. This study was funded by a Natural Sciences and Engineering Research Council of Canada (NSERC) Supplemental Strategic Grant to D.D., C.H.M., M. L. Rise, and R.J.T., and by the NSERC Discovery grants of D.D. and R.J.T. Additional support for this study was provided by the Sea Around Us Project, a research initiative at the University of British Columbia funded by the Paul G. Allen Family Foundation.

\section{REFERENCES}

Aitken, A. E., and Fournier, J. 1993. Macrobenthos communities of Cambridge, McBeth and Itirbilung Fjords, Baffin Island, Northwest Territories, Canada. Arctic, 46 (1): 60-71.

Arens, C. J., Paetzold, S. C., and Davidson, J. 2011a. The effect of high-pressure spraying for tunicate control on byssal thread characteristics in the cultured blue mussel (Mytilus edulis Linnaeus, 1758). Aquat. Invasions, 6 (4): 507-510.

Arens, C. J., Paetzold, S. C., Ramsay, A., and Davidson, J. 2011b. Pressurized seawater as an antifouling treatment against the colonial tunicates Botrylloides violaceus and Botryllus schlosseri in mussel aquaculture. Aquat. Invasions, 6 (4): 465-476.

Arsenault, G., Davidson, J., and Ramsay, A. 2009. Temporal and spatial development of an infestation of Styela clava on mussel farms in Malpeque Bay, Prince Edward Island, Canada. Aquat. Invasions, 4 (1): 189-194.

Atkinson, E. G., and Wacasey, J. W. 1989. Benthic invertebrates collected from Hudson Strait, Foxe Channel and Foxe Basin, Canada, 1949 to 1970. Can. Data Rep. of Fish. Aquat. Sci. 746.

Bernier, R. Y., Locke, A., and Hanson, J. M. 2009. Lobster and crabs as potential vectors for tunicate dispersal in the southern Gulf of St. Lawrence, Canada. Aquat. Invasions, 4 (1): 105-110.

Berrill, N. J. 1928. The identification and validity of certain species of ascidians. J. Mar. Biol. Assoc. U.K. 
15 (1): 159-175.

Berrill, N. J. 1950. The Tunicata: With an account of the British species. The Ray Society, London.

Bock, D. G., Zhan, A., Lejeusne, C., MacIsaac, H. J., and Cristescu, M. E. 2011. Looking at both sides of the invasion: patterns of colonization in the violet tunicate Botrylloides violaceus. Mol. Ecol. 20 (3): 503516.

Bock, D. G., MacIsaac, H. J., and Cristescu, M. E. 2012. Multilocus genetic analyses differentiate between widespread and spatially restricted cryptic species in a model ascidian. Proc. R. Soc. Lond. B Biol. Sci. 279 (1737): 2377-2385.

Bourget, E. 1997. Les animaux littoraux du Saint-Laurent: Guide d'identification. Les Presses de l’Université Laval, Québec.

Bourque, D., Landry, T., Davidson, J., and McNair, N. 2003. Impact of an invasive tunicate in Atlantic Canada: Recruitment and competition. J. Shellfish Res. 22: 320.

Bourque, D., Davidson, J., MacNair, N. G., Arsenault, G., LeBlanc, A. R., Landry, T., and Miron, G. 2007. Reproduction and early life history of an invasive ascidian Styela clava Herdman in Prince Edward Island, Canada. J. Exp. Mar. Biol. Ecol. 342 (1): 78-84.

Brinkhurst, R. O., Linkletter, L. E., Lord, E. I., Connors, S. A., and Dadswell, M. J. 1975. A preliminary guide to the littoral and sublittoral marine invertebrates of Passamaquoddy Bay. The Huntsman Marine Laboratory, St. Andrews.

Brunel, P., Bossé, L., and Lamarche, G. 1998. Catalogue of the marine invertebrates of the Estuary and Gulf of Saint Lawrence. Can. Spec. Publ. Fish. Aquat. Sci. 126.

Brunetti, R., Gissi, C., Pennati, R., Caicci, F., Gasparini, F., and Manni, L. 2015. Morphological evidence that the molecularly determined Ciona intestinalis type A and type B are different species: Ciona robusta and Ciona intestinalis. J. Zool. Syst. Evol. Res. 53: 186-193.

Bullard, S. G., Lambert, G., Carman, M. R., Byrnes, J., Whitlatch, R. B., Ruiz, G., Miller, R. J., Harris, L., Valentine, P. C., Collie, J. S., Pederson, J., McNaught, D. C., Cohen, A. N., Asch, R. G., Dijkstra, J., and Heinonen, K. 2007. The colonial ascidian Didemnum sp. A: Current distribution, basic biology and potential threat to marine communities of the northeast and west coasts of North America. J. Exp. 
Mar. Biol. Ecol. 342 (1): 99-108.

Caddy, J. F. 1970. Records of associated fauna in scallop dredge hauls from the Bay of Fundy. Fish. Res. Board Can. Tech. Rep. 225.

Callahan, A. G., Deibel, D., McKenzie, C. H., Hall, J. R., and Rise, M. L. 2010. Survey of harbours in Newfoundland for indigenous and non-indigenous ascidians and an analysis of their cytochrome $c$ oxidase I gene sequences. Aquat. Invasions, 5 (1): 31-39.

Caputi, L., Andreakis, N., Mastrototaro, F., Cirino, P., Vassillo, M., and Sordino, P. 2007. Cryptic speciation in a model invertebrate chordate. Proc. Natl. Acad. Sci. U.S.A. 104 (22): 9364-9369.

Carlton, J. T. 1979. History, biogeography, and ecology of the introduced marine and estuarine invertebrates of the Pacific coast of North America. Doctor of Philosophy thesis, University of California, Davis.

Carlton, J. T. 2009. Deep invasion ecology and the assembly of communities in historical time. In Biological invasions in marine ecosystems. Edited by G. Rilov, and J. A. Crooks. Springer-Verlag, Berlin, pp. 13-56.

Carman, M. R., Colarusso, P. D., Nelson, E. P., Grunden, D. W., Wong, M. C., McKenzie, C. H., Matheson, K., Davidson, J., Fox, S., Neckles, H. A., Bayley, H., Schott, S., Dijkstra, J. A., and Stewart-Clarke, S. 2016. Distribution and diversity of tunicates utilizing eelgrass as substrate in the western North Atlantic between $39^{\circ}$ and $47^{\circ}$ north latitude (New Jersey to Newfoundland). Manag. Biol. Invasions, 7 (1): 51 57.

Carman, M. R., Morris, J. A., Karney, R. C., and Grunden, D. W. 2010. An initial assessment of native and invasive tunicates in shellfish aquaculture of the North American east coast. J. Appl. Ichthyol. 26 (Supplement s2): 8-11.

Carver, C. E., Chisholm, A., and Mallet, A. L. 2003. Strategies to mitigate the impact of Ciona intestinalis (L.) biofouling on shellfish production. J. Shellfish Res. 22 (3): 621-631.

Carver, C. E., Mallet, A. L., and Vercaemer, B. 2006a. Biological synopsis of the solitary tunicate Ciona intestinalis. Can. Manuscr. Rep. Fish. Aquat. Sci. 2746. 
Carver, C. E., Mallet, A. L., and Vercaemer, B. 2006b. Biological synopsis of the colonial tunicates, Botryllus schlosseri and Botrylloides violaceus. Can. Manuscr. Rep. Fish. Aquat. Sci. 2747.

Clarke, C. L., and Therriault, T. W. 2007. Biological synopsis of the invasive tunicate Styela clava (Herdman 1881). Can. Manuscr. Rep. Fish. Aquat. Sci. 2807.

Cole, L. L. 1989. Catalog of tunicate type specimens in the United States National Museum collections. Smithsonian Contributions to Zoology 487.

Collin, S. B., Edwards, P. K., Leung, B., and Johnson, L. E. 2013. Optimizing early detection of nonindigenous species: Estimating the scale of dispersal of a nascent population of the invasive tunicate Ciona intestinalis (L.). Mar. Pollut. Bull. 73 (1): 64-69.

Collin, S. B., and Johnson, L. E. 2014. Invasive species contribute to biotic resistance: negative effect of caprellid amphipods on an invasive tunicate. Biol. Invasions, 16 (10): 2209-2219.

Daigle, R. M., and Herbinger, C. M. 2009. Ecological interactions between the vase tunicate (Ciona intestinalis) and the farmed blue mussel (Mytilus edulis) in Nova Scotia, Canada. Aquat. Invasions, 4 (1): 177-187.

Darbyson, E. A., Hanson, J. M., Locke, A., and Willison, J. H. M. 2009a. Settlement and potential for transport of clubbed tunicate (Styela clava) on boat hulls. Aquat. Invasions, 4 (1): 95-103.

Darbyson, E., Locke, A., Hanson, J. M., and Willison, J. H. M. 2009b Marine boating habits and the potential for spread of invasive species in the Gulf of St. Lawrence. Aquat. Invasions, 4 (1): 87-94.

Deibel, D., McKenzie, C. H., Rise, M. L., Thompson, R. J., Lowen, J. B., Ma, K. C. K., Applin, G., O'Donnell, R., Wells, T., Hall, J. R., Sargent, P., and Pilgrim, B. B. 2014. Recommendations for eradication and control of non-indigenous, colonial, ascidian tunicates in Newfoundland harbours. Can. Manuscr. Rep. Fish. Aquat. Sci. 3039.

Dijkstra, J., Harris, L. G., and Westerman, E. 2007. Distribution and long-term temporal patterns of four invasive colonial ascidians in the Gulf of Maine. J. Exp. Mar. Biol. Ecol. 342 (1): 61-68.

Edwards, P. K., and Leung, B. 2009. Re-evaluating eradication of nuisance species: invasion of the tunicate, Ciona intestinalis. Front. Ecol. Environ. 7 (6): 326-232.

Epelbaum, A., Pearce, C. M., Barker, D. J., Paulson, A., and Therriault, T. W. 2009. Susceptibility of non- 
indigenous ascidian species in British Columbia (Canada) to invertebrate predation. Mar. Biol. 156 (6): 1311-1320.

Ganong, W. F. 1885. On the zoology of the invertebrate animals of Passamaquoddy Bay. Bulletin of the Natural History Society of New Brunswick, 4: 87-97.

GBIF. 2012. Global Biodiversity Information Facility [online]. Available from http://www.gbif.org/ [accessed 30 September 2015].

Goldsmit, J., Howland, K. L., and Archambault, P. 2014. Establishing a baseline for early detection of non-indigenous species in ports of the Canadian Arctic. Aquat. Invasions, 9 (3): 327-342.

Goldstien, S. J., Dupont, L., Viard, F., Hallas, P. J., Nishikawa, T., Schiel, D. R., Gemmell, N. J., and Bishop, J. D. D. 2011. Global phylogeography of the widely introduced north west Pacific ascidian Styela clava. PLoS ONE, 6 (2): e16755. doi:10.1371/journal.pone.0016755.

Gould, A. A. 1870. Report on the invertebrata of Massachusetts, second edition, comprising the mollusca. Wright and Potter, Boston.

Hatfield, C., Logan, A., and Thomas, M. L. H. 1992. Ascidian depth zonation on sublittoral hard substrates off Deer Island, New Brunswick, Canada. Estuarine, Coastal Shelf Sci. 34 (2): 197-202.

Haydar, D. 2010. What is natural? The scale and consequences of marine bioinvasions in the North Atlantic Ocean. Doctor of Philosophy thesis, Rijksuniversiteit Groningen, Groningen.

Hooper, R. 1975. Bonne Bay marine resources: An ecological and biological assessment. Parks Canada Contract No. ARO-74-83.

Howes, S., Herbinger, C. M., Darnell, P., and Vercaemer, B. 2007. Spatial and temporal patterns of recruitment of the tunicate Ciona intestinalis on a mussel farm in Nova Scotia, Canada. J. Exp. Mar. Biol. Ecol. 342 (1): 85-92.

Huntsman, A. G. 1912. Ascidians from the coasts of Canada. Trans. R. Can. Inst. 9 (12): 111-148.

Huntsman, A. G. 1922a. Arctic ascidians. Report of the Canadian Arctic Expedition 1913-18, Volume VI: Fishes and tunicates, Part B: Ascidiacea. F. A. Acland, Ottawa.

Huntsman, A. G. 1922b. Results of the Hudson Bay Expedition, 1920: IV. The Ascidiacea. Contrib. Can. Biol. Fish. 1 (1): 27-38. 
Kanary, L., Locke, A., and Watmough, J. 2010. Evaluating the effectiveness of SCUBA-based visual searches for an invasive tunicate, Ciona intestinalis, in a Prince Edward Island estuary. Aquat. Invasions, 5 (1): 41-47.

Kanary, L., Locke, A., Watmough, J., Chassé, J., Bourque, D., and Nadeau, A. 2011. Predicting larval dispersal of the vase tunicate Ciona intestinalis in a Prince Edward Island estuary using a matrix population model. Aquat. Invasions, 6 (4): 491-506.

Kim, K. C., and Byrne, L. B. 2006. Biodiversity loss and the taxonomic bottleneck: emerging biodiversity science. Ecol. Res. 21 (6): 794-810.

Kindle, E. M. 1917. Notes on the bottom environment of the marine invertebrates of western Nova Scotia. Ottawa Nat. 30 (12): 149-154.

Korczynski, R. E. 1989. A new species of solitary ascidian (Ascidacea: Pyuridae) from Mason Bay, Northwest Territories, Canada. J. Nat. Hist. 23 (1): 219-224.

Lacoursière-Roussel, A., Bock, D. G., Cristescu, M. E., Guichard, F., Girard, P., Legendre, P., and McKindsey, C. W. 2012. Disentangling invasion processes in a dynamic shipping-boating network. Mol. Ecol. 21 (17): 4227-4241.

Lambert, G. 2003. New records of ascidians from the NE Pacific: a new species of Trididemnum, range extension and redescription of Aplidiopsis pannosum (Ritter, 1899) including its larva, and several non-indigenous species. Zoosystema, 25 (4): 665-679.

Lambert, G. 2007. Invasive sea squirts: A growing global problem. J. Exp. Mar. Biol. Ecol. 342 (1): 3-4.

Lambert, G. 2009. Adventures of a sea squirt sleuth: Unraveling the identity of Didemnum vexillum, a global ascidian invader. Aquat. Invasions, 4 (1): 5-28.

Lambert, C. C., and Lambert, G. 1998. Non-indigenous ascidians in southern California harbors and marinas. Mar. Biol. 130 (4): 675-688.

Lambert, C. C., and Lambert, G. 2003. Persistence and differential distribution of nonindigenous ascidians in harbors of the Southern California Bight. Mar. Ecol. Prog. Ser. 259: 145-161.

LeBlanc, A. R., Landry, T., and Miron, G. 2003. Identification of fouling organisms covering mussel lines and impact of a common defouling method on the abundance of foulers in Tracadie Bay, Prince 
Edward Island. Can. Tech. Rep. Fish. Aquat. Sci. 2477.

LeGresley, M. M., Martin, J. L., McCurdy, P., Thorpe, B., and Chang, B. D. 2008. Non-indigenous tunicate species in the Bay of Fundy, eastern Canada. ICES J. Mar. Sci. 65 (5): 770-774.

Lejeusne, C., Bock, D. G., Therriault, T. W., MacIsaac, H. J., and Cristescu, M. E. 2011. Comparative phylogeography of two colonial ascidians reveals contrasting invasion histories in North America. Biol. Invasions, 13 (3): 635-650.

Linkletter, L. E., Lord, E. I., and Dadswell, M. J. 1977. A checklist and catalogue of the marine fauna and flora of the Lower Bay of Fundy shore of New Brunswick. The Huntsman Marine Laboratory, St. Andrews.

Locke, A. 2009. A screening procedure for potential tunicate invaders of Atlantic Canada. Aquat. Invasions, 4 (1): 71-79.

Locke, A., and Carman, M. 2009. An overview of the 2nd International Invasive Sea Squirt Conference: What we learned. Aquat. Invasions, 4 (1): 1-4.

Locke, A., and Hanson, J. M. 2009. Rapid response to non-indigenous species. 3. A proposed framework. Aquat. Invasions, 4 (1): 259-273.

Locke, A., Doe, K. G., Fairchild, W. L., Jackman, P. M., and Reese, E. J. 2009a. Preliminary evaluation of effects of invasive tunicate management with acetic acid and calcium hydroxide on non-target marine organisms in Prince Edward Island, Canada. Aquat. Invasions, 4 (1): 221-236.

Locke, A., Hanson, J. M., Ellis, K. M., Thompson, J., and Rochette, R. 2007. Invasion of the southern Gulf of St. Lawrence by the clubbed tunicate (Styela clava Herdman): Potential mechanisms for invasions of Prince Edward Island estuaries. J. Exp. Mar. Biol. Ecol. 342 (1): 69-77.

Locke, A., Hanson, J. M., MacNair, N. G., and Smith, A. H. 2009b. Rapid response to non-indigenous species. 2. Case studies of invasive tunicates in Prince Edward Island. Aquat. Invasions, 4 (1): 249258.

Logan, A. 1988. A sublittoral hard substrate epibenthic community below 30 m in Head Harbour Passage, New Brunswick, Canada. Estuarine, Coastal Shelf Sci. 27 (4): 445-459.

Logan, A., MacKay, A. A., and Noble, J. P. A. 1983. Sublittoral Hard Substrates. In Marine and Coastal 
Systems of the Quoddy Region, New Brunswick. Edited by M. L. H. Thomas. Can. Spec. Publ. Fish. Aquat. Sci. 64, pp. 118-139.

Logan, A., Page, F. H., and Thomas, M. L. H. 1984. Depth zonation of epibenthos on sublittoral hard substrates off Deer Island, Bay of Fundy, Canada. Estuarine, Coastal Shelf Sci. 18 (5): 571-592.

Longhurst, A. 2007. Ecological geography of the sea, 2nd Edition. Academic Press, New York.

Lowen, J. B., Deibel, D., McKenzie, C. H., Couturier, C., and DiBacco, C. 2016. Tolerance of early life-stages in Ciona intestinalis to bubble streams and suspended particles. Manag. Biol. Invasions, 7 (2): 157165.

Lutz-Collins, V., Ramsay, A., Quijón, P. A., and Davidson, J. 2009. Invasive tunicates fouling mussel lines: evidence of their impact on native tunicates and other epifaunal invertebrates. Aquat. Invasions, 4 (1): 213-220.

Ma, K. C. K., Deibel, D., and McKenzie, C. 2011. Indigenous and non-indigenous ascidian tunicates of Newfoundland and Labrador. Proceedings of the Contributed Papers of the $27^{\text {th }}$ Annual General Meeting of the Aquaculture Association of Canada, Aquaculture Association of Canada Special Publication No. 17: 58-63.

Mackenzie, A. B. 2011. Biological synopsis of the compound sea squirt (Diplosoma listerianum). Can. Manuscr. Rep. Fish. Aquat. Sci. 2966.

Martin, J. L., LeGresley, M. M., Cooper, J. A., Thorpe, J. A., Locke, A., Simard, N., Sephton, D., Bernier, R., Bérubé, I., Hill, B., Keays, J., Knox, D., Landry, T., Lander, T., Nadeau, A., and Watson, E. 2010. Rapid assessment for Didemnum vexillum in southwest New Brunswick. Can. Tech. Rep. Fish. Aquat. Sci. 2882.

Martin, J. L., LeGresley, M. M., Thorpe, B., and McCurdy, P. 2011. Non-indigenous tunicates in the Bay of Fundy, eastern Canada (2006-2009). Aquat. Invasions, 6 (4): 405-412.

McKenzie, C. H., Matheson, K., Caines, S., and Wells, T. 2016. Surveys for non-indigenous tunicate species in Newfoundland, Canada (2006 - 2014): a first step towards understanding impact and control. Manag. Biol. Invasions, 7 (1): 21-32.

McKindsey, C. W., Landry, T., O’Beirn, F. X., and Davies, I. M. 2007. Bivalve aquaculture and exotic 
species: A review of ecological considerations and management issues. J. Shellfish Res. 26 (2): 281294.

McKindsey, C. W., Lecuona, M., Huot, M., and Weise, A. M. 2009. Biodeposit production and benthic loading by farmed mussels and associated tunicate epifauna in Prince Edward Island. Aquaculture, 295 (1-2): 44-51.

McLaughlin, J., Bourque, D., LeBlanc, A. R., and Fortin, G. 2013. Effect of suspended inorganic matter on fertilization success, embryonic development, larval settlement, and juvenile survival of the vase tunicate Ciona intestinalis (Linnaeus, 1767). Aquat. Invasions, 8 (4): 375-388.

Millar, R. H. 1966. Tunicata Ascidiacea. Marine invertebrates of Scandinavia 1. Universitetsforlaget, Oslo.

Millar, R. H. 1970. British ascidians. Synopses of the British Fauna (New Series) 1. Academic Press, London.

Moore, A. M., Vercaemer, B., DiBacco, C., Sephton, D., and Ma, K. C. K. 2014. Invading Nova Scotia: first records of Didemnum vexillum Kott, 2002 and four more non-indigenous invertebrates in 2012 and 2013. BioInvasions Rec. 3 (4): 225-234.

Nadeau, M. 2008. Évaluation de la présence et de la progression des principales espèces de tuniciers envahissants aux Îles-de-la-Madeleine avec des efforts particuliers sur l'ascidie jaune (Ciona intestinalis). Societé de développement de l'industrie maricole inc., Cap-aux-Meules.

Naranjo, S., Carballo, J. L., and Garcia-Gómez, J. C. 1998. Towards a knowledge of marine boundaries using ascidians as indicators: Characterising transition zones for species distribution along Mediterranean shores. Biol. J. Linn. Soc. 64 (2): 151-177.

OBIS. 2015. Global biodiversity indices from the Ocean Biogeographic Information System. Intergovernmental Oceanographic Commission of UNESCO [online]. Available from http://www.iobis.org/ [accessed 30 September 2015].

Packard Jr., A. S. 1863. A list of animals dredged near Caribou Island, southern Labrador, during July and August, 1860. The Canadian Naturalist and Geologist, 8 (6): 401-429.

Packard Jr., A. S. 1867. Observations on glacial phenomena of Labrador and Maine, with a view of the 
recent invertebrate fauna of Labrador. Memoirs Read Before the Boston Society of Natural History, 1 (2): 210-303.

Paetzold, S. C., and Davidson, J. 2010. Viability of golden star tunicate fragments after high-pressure water treatment. Aquaculture, 303 (1-4): 105-107.

Paetzold, S. C., Giberson, D. J., Hill, J., Davidson, J. D. P., and Davidson, J. 2012. Effect of colonial tunicate presence on Ciona intestinalis recruitment within a mussel farming environment. Manag. Biol. Invasions, 3 (1): 15-23.

Patanasatienkul, T., Revie, C. W., Davidson, J., and Sanchez, J. 2014. Mathematical model describing the population dynamics of Ciona intestinalis, a biofouling tunicate on mussel farms in Prince Edward Island, Canada. Manag. Biol. Invasions, 5 (1): 39-54.

Pellegrin, N., Boutillier, J., Lauzier, R., Verrin, S., and Johannessen, D. 2007. Appendix F: Invertebrates. In Ecosystem overview: Pacific North Coast Integrated Management Area (PNCIMA). Edited by B. G. Lucas, S. Verrin, and R. Brown. Can. Tech. Rep. Fish. Aquat. Sci. 2667.

Plough, H. H. 1978. Sea squirts of the Atlantic continental shelf from Maine to Texas. Johns Hopkins University Press, Baltimore.

Ramsay, A., Davidson, J., Bourque, D., and Stryhn, H. 2009. Recruitment patterns and population development of the invasive ascidian Ciona intestinalis in Prince Edward Island, Canada. Aquat. Invasions, 4 (1): 169-176.

Ramsay, A., Davidson, J., Landry, T., and Stryhn, H. 2008a. The effect of mussel seed density on tunicate settlement and growth for the cultured mussel, Mytilus edulis. Aquaculture, 275 (1-4): 194-200.

Ramsay, A., Davidson, J., Landry, T., and Arsenault, G. 2008b. Process of invasiveness among exotic tunicates in Prince Edward Island, Canada. Biol. Invasions, 10 (8): 1311-1316.

Sargent, P. S., Wells, T., Matheson, K., McKenzie, C. H., and Deibel, D. 2013. First record of vase tunicate, Ciona intestinalis (Linnaeus, 1767) in coastal Newfoundland waters. BioInvasions Rec. 2 (2): 89-98.

Schander, C., and Willassen, E. 2005. What can biological barcoding do for marine biology? Mar. Biol. Res. 1 (1): 79-83.

Sephton, D., Vercaemer, B., Nicolas, J. M., and Keays, J. 2011. Monitoring for invasive tunicates in Nova 
Scotia, Canada (2006-2009). Aquat. Invasions, 6 (4): 391-403.

Shenkar, N., and Swalla, B. J. 2011. Global diversity of Ascidiacea. PLoS ONE, 6 (6): e20657. doi:10.1371/journal.pone.0020657.

Siah, A., and McKenna, P. 2013. Rapid detection assay for the invasive vase tunicate, Ciona intestinalis, using loop-mediated isothermal amplification combined with lateral flow dipstick. Manag. Biol. Invasions, 4 (1): 81-86.

Simard, N., Pereira, S., Estrada, R., and Nadeau, M. 2013. État de la situation des espèces envahissantes marines du Québec. Rapp. manus. Can. sci. halieut. aquat. 3020.

Smith, G., and Ramsay, A. 2014. PEI Mussel Monitoring Program 2014 Report, Technical Report \#254. Prince Edward Island Department of Fisheries, Aquaculture and Rural Development, Aquaculture Division, Montague.

Sørensen, T. 1948. A method of establishing groups of equal amplitude in plant sociology based on similarity of species and its application to analyses of the vegetation on Danish commons. Biol. Skr. 5 (4): $1-34$.

Spalding, M. D., Fox, H. E., Allen, G. R., Davidson, N., Ferdaña, Z. A., Finlayson, M., Halpern, B. S., Jorge, M. A., Lombana, A., Lourie, S. A., Martin, K. D., McManus, E., Molnar, J., Recchia, C. A., and Robertson, J. 2007. Marine ecoregions of the world: A bioregionalization of coastal and shelf areas. BioScience, 57 (7): 573-583.

Stachowicz, J. J., Terwin, J. R., Whitlatch, R. B., and Osman, R. W. 2002. Linking climate change and biological invasions: Ocean warming facilitates nonindigenous species invasions. Proc. Natl. Acad. Sci. U.S.A. 99 (24): 15497-15500.

Stafford, J. 1906. On the fauna of the Atlantic coast of Canada: Third report - Gaspe, 1905-1906. Contrib. Can. Biol. Fish. B (1): 45-67.

Stefaniak, L., Zhang, H., Gittenberger, A., Smith, K., Holsinger, K., Lin, S., and Whitlatch, R. B. 2012. Determining the native region of the putatively invasive ascidian Didemnum vexillum Kott, 2002. J. Exp. Mar. Biol. Ecol. 422-423: 64-71.

Stewart-Clark, S. E., Siah, A., Greenwood, S. J., Davidson, J., and Berthe, F. C. J. 2009. Development of 18 S 
rDNA and COI gene primers for the identification of invasive tunicate species in water samples. Aquat. Invasions, 4 (1): 575-580.

Stewart-Clark, S. E., Davidson, J., and Greenwood, S. J. 2013. Monitoring for propagules of Ciona intestinalis in marine water samples: the development of temporal gene expression markers for viability and life stage specific assays. Manag. Biol. Invasions, 4 (3): 207-217.

Stimpson, W. 1852. Several new ascidians from the coast of the United States. Proc. Boston Soc. Nat. Hist. 4: 228-232.

Stimpson, W. 1854. Synopsis of the marine Invertebrata of Grand Manan: Or the region about the mouth of the Bay of Fundy, New Brunswick. Smithsonian Contributions to Knowledge 6.

Therriault, T. W., and Herborg L.-M. 2008a. Risk assessment of two solitary and three colonial tunicates in both Atlantic and Pacific Canadian waters. Fisheries and Oceans Canada, Canadian Science Advisory Secretariat, Research Document 2007/063.

Therriault, T. W., and Herborg, L.-M. 2008b. Predicting the potential distribution of the vase tunicate Ciona intestinalis in Canadian waters: Informing a risk assessment. ICES J. Mar. Sci. 65 (5): 788-794. Trason, W. B. 1964. Ascidians of the Canadian Arctic waters. J. Fish. Res. Board Can. 21 (6): 1505-1517. United States Navy. 1951. Report on marine borers and fouling organisms in 56 important harbors and tabular summaries of marine borer data from 160 widespread locations. Bureau of Yards and Docks, Department of the Navy, Washington, D.C.

Van Name, W. G. 1910. Compound ascidians of the coasts of New England and neighboring British Provinces. Proc. Boston Soc. Nat. Hist. 34 (11): 339-424.

Van Name, W. G. 1912. Simple ascidians of the coasts of New England and neighboring British Provinces. Proc. Boston Soc. Nat. Hist. 34 (13): 439-619.

Van Name, W. G. 1921. Ascidians of the West Indian region and southeastern United States. Bull. Am. Mus. Nat. Hist. 44: 283-494.

Van Name, W. G. 1945. The North and South American ascidians. Bull. Am. Mus. Nat. Hist. 84: 1-476.

Vercaemer, B., Sephton, D., Nicolas, J. M., Howes, S., and Keays, J. 2011. Ciona intestinalis environmental control points: field and laboratory investigations. Aquat. Invasions, 6 (1): 477-490. 
Vercaemer, B., Bugden, G., Roach, S., and Clément, P. 2012. Small buoy surveys: pilot study for invasive tunicates monitoring. Can. Tech. Rep. Fish. Aquat. Sci. 3013.

Vercaemer, B., Sephton, D., Clément, P., Harman, A., Stewart-Clark, S., and DiBacco, C. 2015. Distribution of the non-indigenous colonial ascidian Didemnum vexillum (Kott, 2002) in the Bay of Fundy and on offshore banks, eastern Canada. Manag. Biol. Invasions, 6 (1): 385-394.

Verrill, A. E. 1871. Descriptions of some imperfectly known ascidians from New England. Am. J. Sci. Arts, 1 (2): 54-58, 93-100, 211-212, 288-294, 443-446.

Whiteaves, J. F. 1901. Catalogue of the marine Invertebrata of eastern Canada. Geol. Surv. Can. 772: 1271.

Wildish, D. J. 1976. Sublittoral macro-infauna of Saint John Harbour, New Brunswick in 1959, 1961, and 1973. Fish. Res. Board Can., Manuscript Report Series, 1409.

Wildish, D. J., and Phillips, R. L. 1974. An identification strategem for benthos collected to assess marine and estuarine pollution. Fish. Res. Board Can., Technical Report, 450.

Wildish, D. J., and Wilson, A. J. 1976. Check list for sublittoral macro-infauna sampled between 1970 and 1975 in four Bay of Fundy estuaries. Fish. Res. Board Can., Manuscript Report Series, 1398.

Wildish, D. J., Wilson, A. J., and Akagi, H. M. 1977. Sublittoral macro-infauna of St. Croix estuary. Fish. Mar. Serv. Manuscr. Rep. (Can.) 1462.

Willis, J. E., Stewart-Clark, S., Greenwood, S. J., Davidson, J., and Quijon, P. 2011. A PCR-based assay to facilitate early detection of Diplosoma listerianum in Atlantic Canada. Aquat. Invasions, 6 (1): 7-16.

WoRMS Editorial Board. 2015. World Register of Marine Species [online]. Available from http://www.marinespecies.org/ [accessed 12 December 2015].

Yund, P. O., Collins, C., and Johnson S. L. 2015. Evidence of a native Northwest Atlantic COI haplotype clade in the cryptogenic colonial ascidian Botryllus schlosseri. Biol. Bull. 228: 201-16.

Zhan, A., Briski, E., Bock, D. G., Ghabooli, S., and MacIsaac, H. J. 2015. Ascidians as models for studying invasion success. Mar. Biol. 162 (12): 2449-2470.

Zhan, A., Darling J. A., Bock, D. G., Lacoursière-Roussel, A., MacIsaac, H. J., and Cristescu, M. E. 2012. Complex genetic patterns in closely related colonizing invasive species. Ecol. Evol. 2 (7): 1331-1346. 
Zhan, A., MacIsaac, H. J., and Cristescu, M. E. 2010. Invasion genetics of the Ciona intestinalis species complex: From regional endemism to global homogeneity. Mol. Ecol. 19 (21): 4678-4694. 
Figure 1 Map of eastern Canada showing the ten regions under consideration in this study: (1) the Arctic, (2) Labrador, (3) insular Newfoundland, (4) the Atlantic waters of Nova Scotia, (5) the Gulf of St. Lawrence waters of Quebec, (6) Prince Edward Island, (7) the Gulf of St. Lawrence waters of New Brunswick, (8) the Gulf of St. Lawrence waters of Nova Scotia, (9) the Bay of Fundy waters of New Brunswick, and (10) the Bay of Fundy waters of Nova Scotia. NB = New Brunswick; NL = Newfoundland and Labrador; NS = Nova Scotia; PEI = Prince Edward Island .

Figure 2 Common indigenous ascidian species found in eastern Canada. (A) Dendrodoa carnea; (B) Aplidium glabrum; (C) Ascidia callosa; (D) Boltenia echinata; (E) Didemnum albidum encrusting Molgula sp.; (F) Halocynthia pyriformis. Scale bars $=1 \mathrm{~cm}$.

Figure 3 Non-metric, multidimensional scaling of the fauna of ascidian species from nine regions of eastern Canada showing four zoogeographic clusters. BoF = Bay of Fundy; GoSL = Gulf of St. Lawrence. 


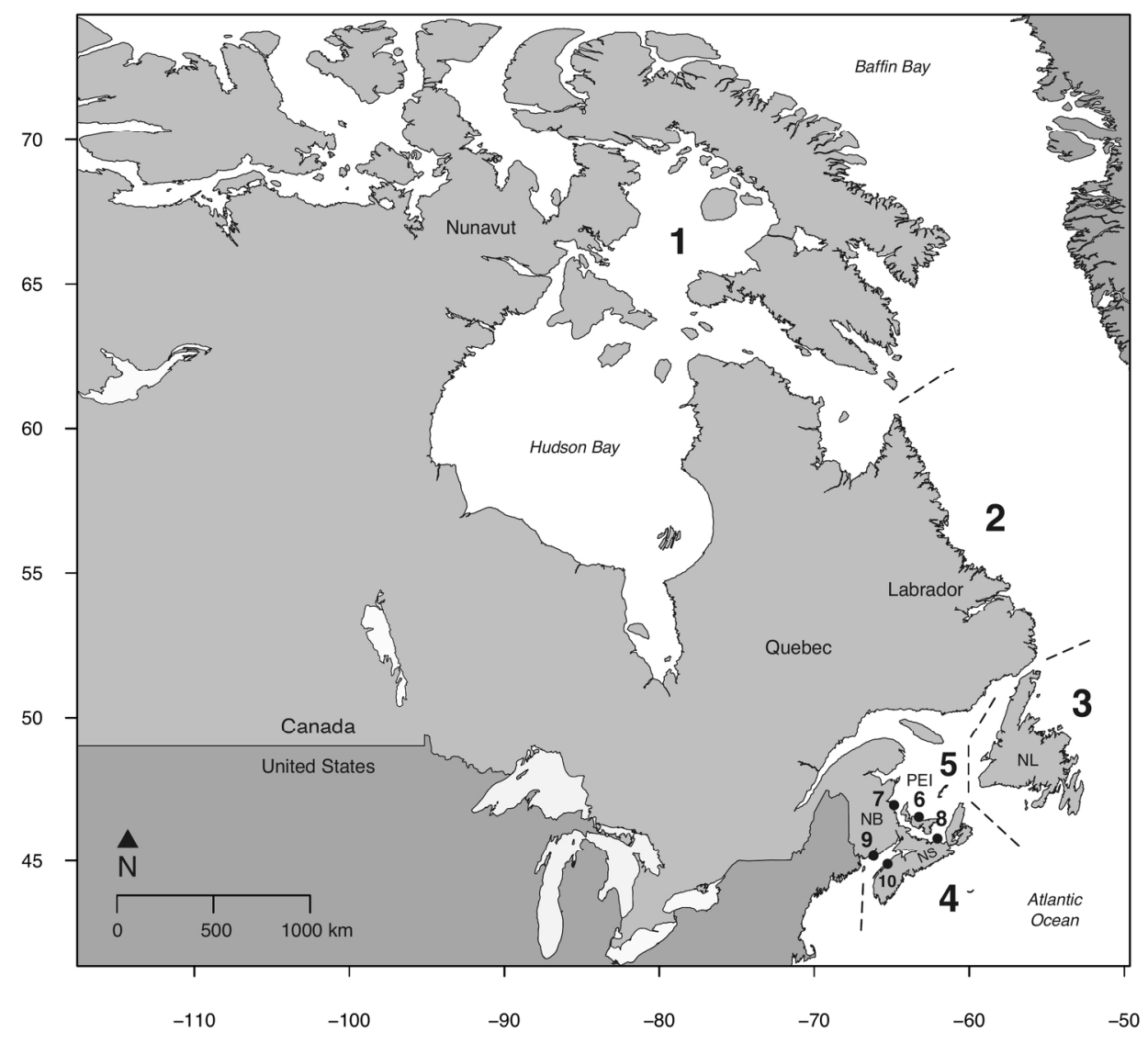

Map of eastern Canada showing the ten regions under consideration in this study: (1) the Arctic, (2) Labrador, (3) insular Newfoundland, (4) the Atlantic waters of Nova Scotia, (5) the Gulf of St. Lawrence waters of Quebec, (6) Prince Edward Island, (7) the Gulf of St. Lawrence waters of New Brunswick, (8) the Gulf of St. Lawrence waters of Nova Scotia, (9) the Bay of Fundy waters of New Brunswick, and (10) the Bay of Fundy waters of Nova Scotia. NB = New Brunswick; NL = Newfoundland and Labrador; NS = Nova Scotia; PEI = Prince Edward Island.

$177 \times 177 \mathrm{~mm}(300 \times 300 \mathrm{DPI})$ 
A

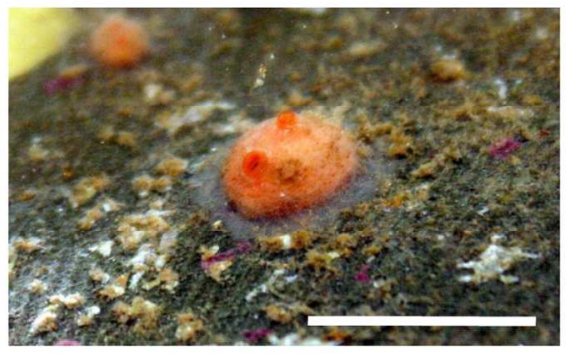

C

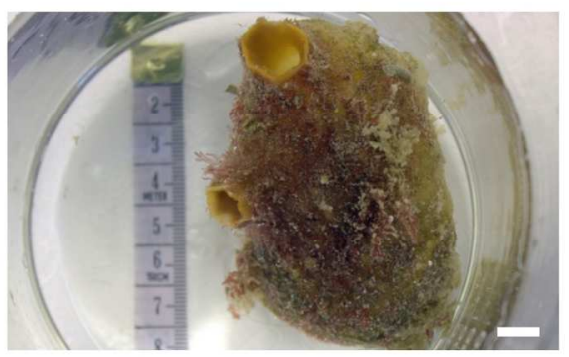

E

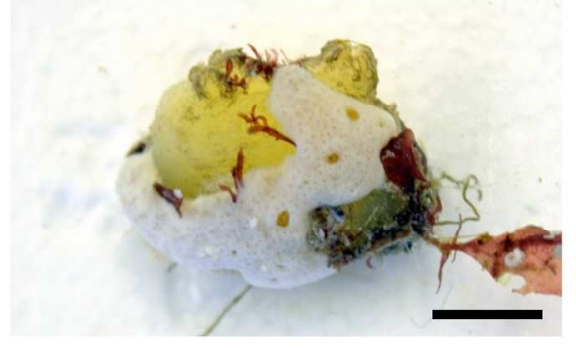

B

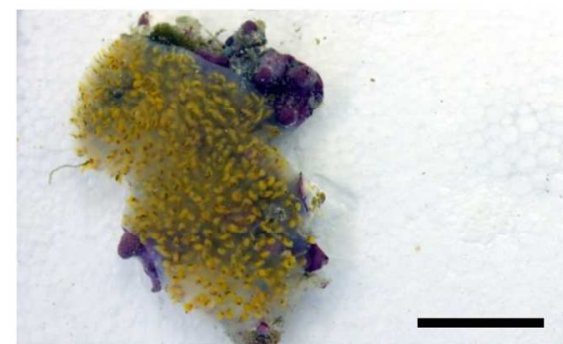

D

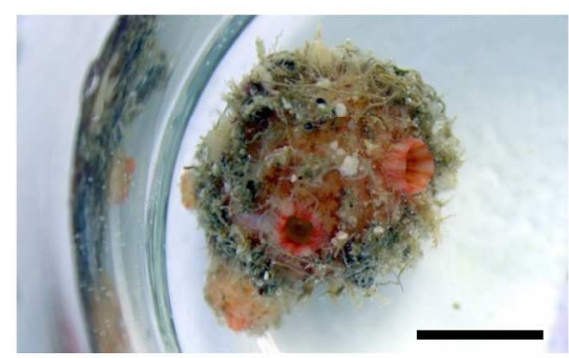

$\mathbf{F}$

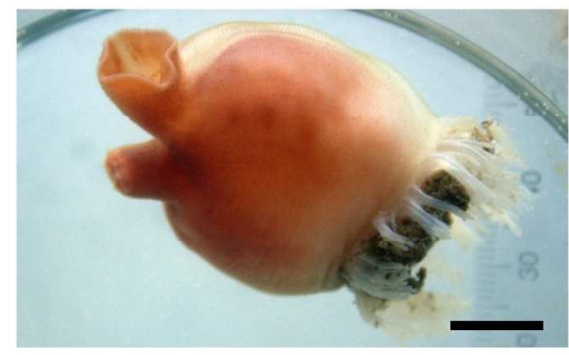

Common indigenous ascidian species found in eastern Canada. (A) Dendrodoa carnea; (B) Aplidium glabrum; (C) Ascidia callosa; (D) Boltenia echinata; (E) Didemnum albidum encrusting Molgula sp.; (F) Halocynthia pyriformis. Scale bars $=1 \mathrm{~cm}$.

$154 \times 133 \mathrm{~mm}(300 \times 300 \mathrm{DPI})$ 


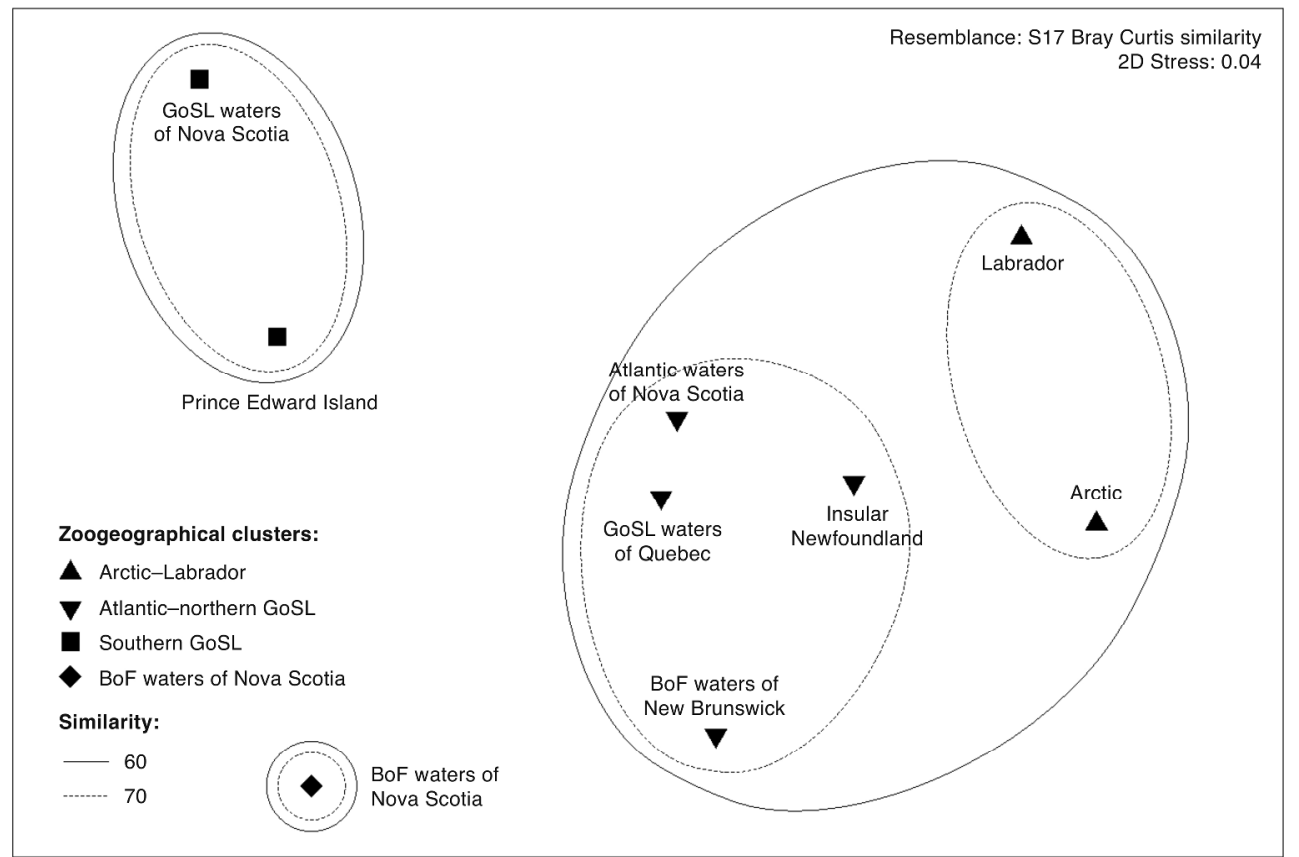

Non-metric, multidimensional scaling of the fauna of ascidian species from nine regions of eastern Canada showing four zoogeographic clusters. BoF = Bay of Fundy; GoSL = Gulf of St. Lawrence.

$363 \times 244 \mathrm{~mm}(300 \times 300$ DPI) 
Table 1 List of ascidian species, with fewer than two records in eastern Canada, that were excluded from the checklist.

\begin{tabular}{|c|c|c|}
\hline Species & Region & Source(s) of record \\
\hline Aplidium translucidum (Ritter, 1901) & Labrador & GBIF (2015), OBIS (2015) \\
\hline Araneum sigma Monniot C. \& Monniot F., 1973 & Labrador & GBIF (2015) \\
\hline Clavelina concrescens Hartmeyer, 1924 & Arctic & Van Name (1945) \\
\hline Eugyra pedunculata Traustedt, 1886 & Arctic & OBIS (2015) \\
\hline Lissoclinum wandeli Hartmeyer, 1924 & Arctic & Van Name (1945) \\
\hline Minipera papillosa Monniot C. \& Monniot F., 1974 & Labrador & OBIS (2015) \\
\hline Minipera pedunculata Monniot C. \& Monniot F., 1974 & Labrador & OBIS (2015) \\
\hline Molgula occidentalis Traustedt, 1883 & Gulf of St. Lawrence waters of Quebec & Brunel et al. (1998) \\
\hline Molgula pugetiensis Herdman, 1898 & Insular Newfoundland & OBIS (2015) \\
\hline Polycarpa spongiabilis Traustedt, 1883 & Atlantic waters of Nova Scotia & GBIF (2015) \\
\hline Pseudodiazona abyssa Monniot C. \& Monniot F., 1974 & Labrador & GBIF (2015) \\
\hline Styela gelatinosa (Traustedt, 1886) & Arctic & Van Name (1945), Millar (1966) \\
\hline Styela squamosa Herdman, 1881 & Atlantic waters of Nova Scotia & GBIF (2015), OBIS (2015) \\
\hline
\end{tabular}


Table 2 Checklist of 58 extant ascidian species of eastern Canada. BoF = Bay of Fundy; GoSL = Gulf of St. Lawrence; NB = New Brunswick; NS = Nova Scotia. References are given in Appendix 1. The authority name and year, distribution, and status for each species are listed in Appendix 2.

\begin{tabular}{|c|c|c|c|c|c|c|c|c|c|c|}
\hline \multirow[t]{2}{*}{ Species } & \multicolumn{10}{|c|}{ Region } \\
\hline & 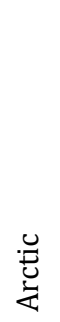 & $\begin{array}{l}\tilde{0} \\
\frac{\pi}{\pi} \\
\tilde{0} \\
\tilde{\sigma}\end{array}$ & 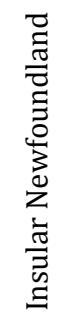 & 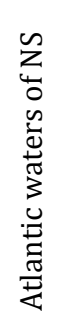 & 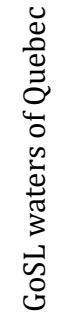 & 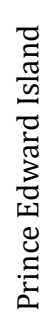 & 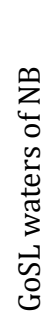 & 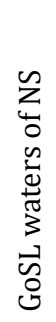 & 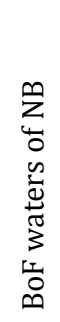 & 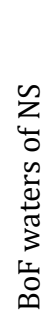 \\
\hline Aplidium glabrum & $x$ & $x$ & $x$ & $x$ & $x$ & & & & $x$ & $x$ \\
\hline Aplidium mutabile & $x$ & & & & & & & & & \\
\hline Aplidium pallidum & $x$ & & $x$ & $x$ & $x$ & & & & $x$ & \\
\hline Aplidium spitzbergense & & & & & & & & & $x$ & \\
\hline Aplidium stellatum & & & & & & & & & $x$ & \\
\hline Ascidia callosa & $x$ & $x$ & $x$ & $x$ & $x$ & & & & $x$ & $x$ \\
\hline Ascidia dijmphniana & $x$ & $x$ & & & & & & & & \\
\hline Ascidia obliqua & $x$ & $x$ & $x$ & $x$ & $x$ & & & & $x$ & \\
\hline Ascidia prunum & $x$ & $x$ & $x$ & $x$ & $x$ & $x$ & & $x$ & $x$ & \\
\hline Ascidiella aspersa & & & & $x$ & & & & & & \\
\hline Boltenia echinata & $\times$ & $x$ & $x$ & $x$ & $x$ & & & & $x$ & $x$ \\
\hline Boltenia ovifera & $\times$ & $x$ & $x$ & $x$ & $x$ & & & & $x$ & $x$ \\
\hline Bostrichobranchus pilularis & & $x$ & $x$ & $x$ & $x$ & $x$ & & & $x$ & $x$ \\
\hline Botrylloides aureum & $\times$ & $x$ & $x$ & & $x$ & & & & & \\
\hline Botrylloides violaceus & & & $x$ & $x$ & $x$ & $x$ & $x$ & $x$ & $x$ & $x$ \\
\hline Botryllus schlosseri & & & $x$ & $x$ & $x$ & $x$ & $x$ & $x$ & $x$ & $x$ \\
\hline Chelyosoma macleayanum & $\times$ & $x$ & & $x$ & $x$ & & & & $x$ & \\
\hline Ciona intestinalis & $x$ & & $x$ & $x$ & $x$ & $x$ & & $x$ & $x$ & $x$ \\
\hline Cnemidocarpa finmarkiensis & $x$ & & $x$ & & & & & & & \\
\hline Cnemidocarpa mollis & $x$ & & & $x$ & $x$ & & & & $x$ & \\
\hline Cnemidocarpa mortenseni & $x$ & & & $x$ & & & & & & \\
\hline Cnemidocarpa rhizopus & $x$ & & & & $x$ & & & & & \\
\hline Corella borealis & $x$ & & & & & & & & & \\
\hline Dendrodoa aggregata & $x$ & $x$ & $x$ & $x$ & $x$ & & & & & \\
\hline
\end{tabular}


Dendrodoa carnea

Dendrodoa grossularia

Dendrodoa pulchella

Didemnum albidum

Didemnum candidum

Didemnum vexillum

Diplosoma listerianum

Distaplia clavata

Eudistoma vitreum

Eugyra glutinans

Halocynthia pyriformis

Hartmeyeria arctica

Heterostigma sp.

Kukenthalia borealis

Leptoclinides faeroensis

Lissoclinum aureum

Microcosmus glacialis

Molgula arenata

Molgula citrina

Molgula complanata

Molgula griffithsii

Molgula manhattensis

Molgula provisionalis

Molgula retortiformis

Molgula siphonalis

Pelonaia corrugata

Polycarpa fibrosa

Rhizomolgula globularis

Styela canopus

Styela clava

Styela coriacea

Styela rustica

Synoicum pulmonaria

Trididemnum tenerum

Number of species

41

Number of published sources

\begin{tabular}{cccccccccc} 
& & & $\times$ & & & & & $\times$ & \\
& & & $\times$ & & $\times$ & & & & \\
$\times$ & $\times$ & $\times$ & $\times$ & $\times$ & $\times$ & & $\times$ & $\times$ & \\
$\times$ & $\times$ & $\times$ & $\times$ & $\times$ & $\times$ & & $\times$ & & \\
$\times$ & $\times$ & $\times$ & & & & & & & \\
& & $\times$ & $\times$ & & & & & & \\
15 & 27 & 36 & 36 & 35 & 17 & 2 & 11 & 34 & 16 \\
10 & 25 & 28 & 19 & 55 & 3 & 7 & 32 & 13 \\
\hline
\end{tabular}

\begin{tabular}{cccccccccc} 
& & & $\times$ & & & & & $\times$ & \\
& & & $\times$ & & $\times$ & & & & \\
$\times$ & $\times$ & $\times$ & $\times$ & $\times$ & $\times$ & & $\times$ & $\times$ & \\
$\times$ & $\times$ & $\times$ & $\times$ & $\times$ & $\times$ & & $\times$ & & \\
$\times$ & $\times$ & $\times$ & & & & & & & \\
& & $\times$ & $\times$ & & & & & & \\
15 & 27 & 36 & 36 & 35 & 17 & 2 & 11 & 34 & 16 \\
10 & 25 & 28 & 19 & 55 & 3 & 7 & 32 & 13 \\
\hline
\end{tabular}
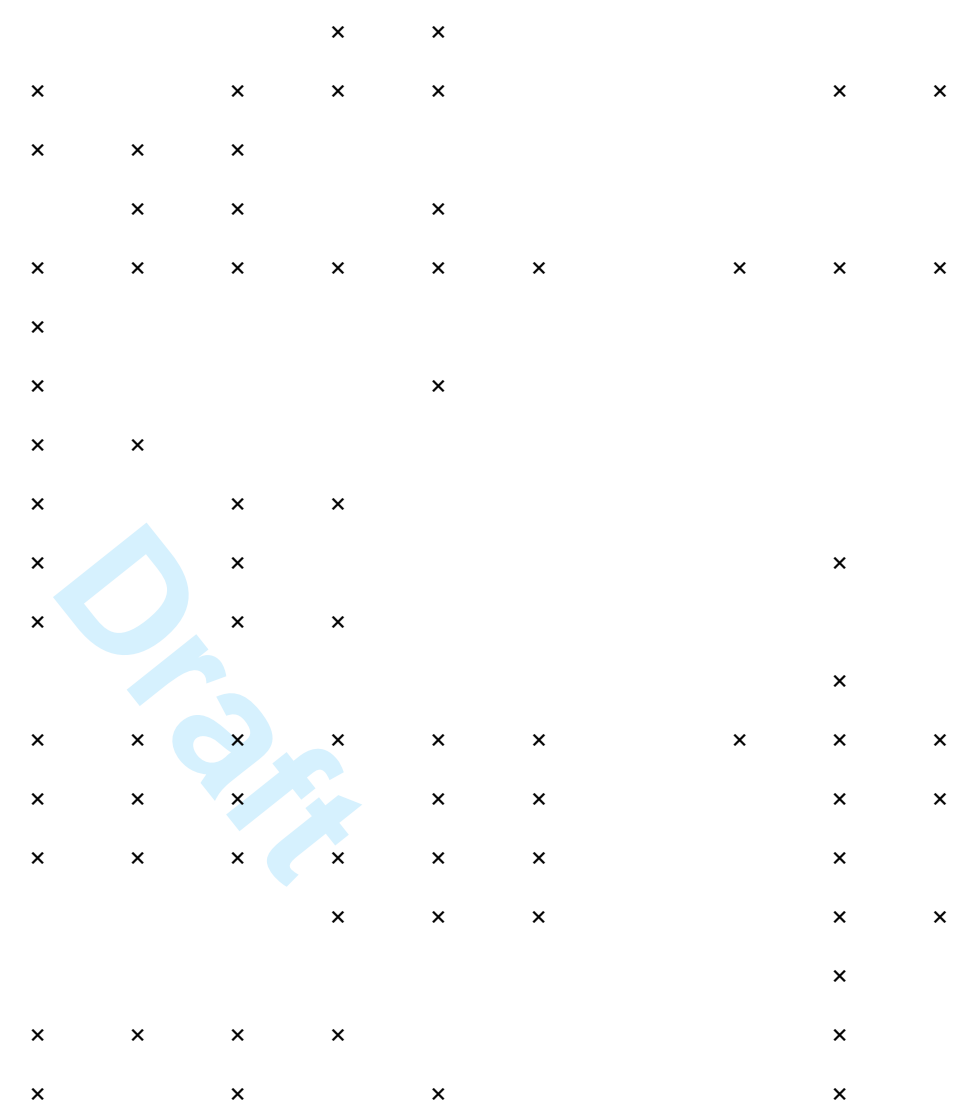
Table 3 Quotient of similarity $(Q S)$ matrix and mean values of $Q S$ per region $( \pm$ one standard deviation; SD). BoF = Bay of Fundy; GoSL = Gulf of St. Lawrence; NB = New Brunswick; NS = Nova Scotia.

\begin{tabular}{|c|c|c|c|c|c|c|c|c|c|c|c|}
\hline & \multicolumn{10}{|c|}{ Region } & \multirow[t]{2}{*}{ Mean $Q S( \pm 1 \mathrm{SD})$} \\
\hline & 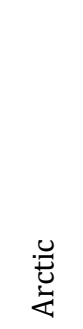 & 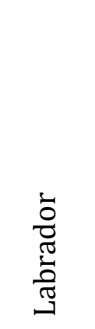 & 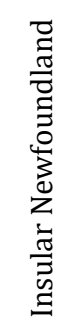 & 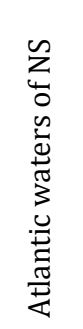 & 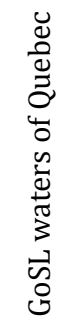 & 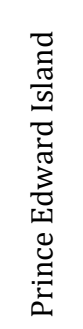 & 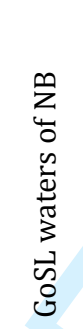 & 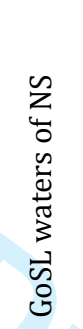 & 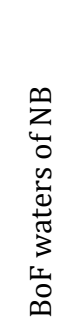 & 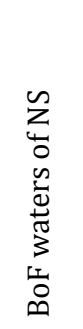 & \\
\hline Arctic & 1.00 & 0.74 & 0.78 & 0.68 & 0.71 & 0.38 & 0.00 & 0.35 & 0.59 & 0.35 & $0.51 \pm 0.26$ \\
\hline Labrador & & 1.00 & 0.73 & 0.60 & 0.68 & 0.45 & 0.00 & 0.37 & 0.52 & 0.42 & $0.50 \pm 0.23$ \\
\hline Insular Newfoundland & & & 1.00 & 0.78 & 0.79 & 0.57 & 0.11 & 0.47 & 0.71 & 0.54 & $0.61 \pm 0.22$ \\
\hline Atlantic waters of NS & & & & 1.00 & 0.79 & 0.60 & 0.11 & 0.47 & 0.74 & 0.54 & $0.59 \pm 0.21$ \\
\hline GoSL waters of Quebec & & & & & 1.00 & 0.62 & 0.11 & 0.48 & 0.75 & 0.59 & $0.61 \pm 0.21$ \\
\hline Prince Edward Island & & & & & & 1.00 & 0.21 & 0.79 & 0.55 & 0.61 & $0.53 \pm 0.16$ \\
\hline GoSL waters of NB & & & & & & & 1.00 & 0.29 & 0.11 & 0.21 & $0.13 \pm 0.10$ \\
\hline GoSL waters of NS & & & & & & & & 1.00 & 0.40 & 0.44 & $0.45 \pm 0.14$ \\
\hline BoF waters of NB & & & & & & & & & 1.00 & 0.60 & $0.55 \pm 0.20$ \\
\hline BoF waters of NS & & & & & & & & & & 1.00 & $0.48 \pm 0.13$ \\
\hline
\end{tabular}


